\title{
The Dynamics Of Stock Market Development In Kenya
}

Sheilla Nyasha, University of South Africa, South Africa

N. M. Odhiambo, University of South Africa, South Africa

\begin{abstract}
This paper highlights the origin of the stock market in Kenya, and traces the reforms that have been undertaken to develop the stock market. It also highlights the growth of the Kenyan stock market, as well as the challenges currently facing the market. The country has one stock market, known as the Nairobi Securities Exchange (formerly the Nairobi Stock Exchange). It is one of Africa's largest stock markets. Since the early 1980s, a number of stock market reforms have been implemented in Kenya. These include the formation of a regulatory body (Capital Markets Authority - CMA) in 1989, the replacement of the "Call-Over" trading system by the floor-based "Open-Outcry System" in 1991, the reduction of listing costs, the relaxation of the exchange control for locally controlled companies, and the repeal of the Exchange Control Act. Following these reforms, Kenya's stock market has developed significantly in terms of market capitalisation, the total value of stocks traded, and the turnover ratio. Although the stock market in Kenya has developed over the years, like many other developing countries' markets, it still faces a number of wide-ranging challenges.
\end{abstract}

Keywords: Kenya; Nairobi Securities Exchange; Stock Market; Reforms

\section{INTRODUCTION}

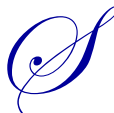

tock market development is an important component of financial sector development, and it supplements the role of the banking system in economic development. Specifically, stock markets assist in price discovery, liquidity provision, reduction in transactions costs, and risk transfer. They reduce information costs through the generation and dissemination of information on firms - thereby, leading to efficient markets, in which prices incorporate all the available information (Yartey \& Adjasi, 2007; Garcia \& Liu, 1999).

Overall, stock markets provide market liquidity that enables the implementation of long-term projects with long-term payoffs, thereby promoting a country's economic growth. Moreover, efficient stock markets not only avail resources to investors, but they also facilitate the inflow of foreign financial resources into the domestic economy (Yartey \& Adjasi, 2007). The role of the stock market in the development of an economy can, therefore, not be overstated.

The Stock market in Kenya is one of the most highly developed stock markets among the Eastern and Central African countries. However, by international standards it is still young and developing. There is one stock exchange in Kenya, known as the Nairobi Securities exchange (NSE), formerly known as the Nairobi Stock Exchange, where the trade in stocks and shares, among other capital market instruments, takes place. The NSE was established in 1954, with 46 listed companies.

Although the stock market in Kenya is still developing, it plays an important role in the process of economic development in Kenya through various ways. These include the mobilisation of domestic savings to bring about the reallocation of financial resources from dormant to active agents, the enhancement of the inflow of international capital, as well as the facilitation of government's privatisation programmes (Capital Markets Authority, 2012a). 
Despite the importance of the stock market in the economic growth process of Kenya, this area has not been fully explored. The documentation on Kenya's stock market is very scant. A lot of work has been done on the bank-based segment of the financial sector in Kenya (Beck et al., 2010), leaving the stock market with very little coverage. This paper, therefore, aims to fill this gap, and to put stock market in the spotlight, by highlighting the origin and growth of the stock market in Kenya - since the establishment of the Nairobi Stock Exchange in 1954.

Long-term capital is deemed crucial for economic development, as evidenced by the positive relationship between long-term capital and economic growth (Demirguc \& Levine, 1996). In recognition of this, Kenya initiated the revitalisation of the stock market in the late 1980s. The reforms undertaken by Kenya as part of the revitalisation process stretched over three decades, and include the formation of a regulatory body (Capital Markets Authority CMA) in 1989, to assist in the creation of an environment conducive to the growth and development of the country's stock market; and the replacement of the "Call-Over" trading system by the floor-based "Open-Outcry System" in 1991.

Despite the extensive reforms implemented in the stock market, the number of listed companies failed to pick up significantly. Currently, the stock market has about 60 listed firms, which is less than the number of listed companies in 1970, a period before the commencement of the reforms. Although the number of listed companied failed to pick up on the growth momentum, market capitalisation, total value traded and turnover ratio have all responded positively to the reforms. They increased in the early 1990s, but declined between 1995 and 2001, before increasing again sharply between 2002 and 2008 (World Bank, 2012). It is worth noting that although these three measures of stock market development have improved over the years, the improvement was not good enough to liberate Kenya's stock market from being labelled "developing".

Despite the stock market revitalising efforts, Kenya's stock market continues to face a number of wideranging challenges. These include: lack of awareness, low investor confidence, lack of competitive pressure in the local market, vulnerability to shocks and low levels of capital-market liquidity. As a result, investors have relied on banks for short-to-medium term loans. Furthermore, savers have had to contend with a thin financial basket. It is interesting to note that although the stock market in Kenya is shallow, narrow and thin by international standards, it remains one of the largest stock markets in Africa; and its role in the development of Kenya's economy can, therefore, not be ignored.

The rest of this paper is organised as follows: Section 2 covers the origin of the stock market in Kenya. Section 3 outlines the reforms implemented to revitalise the stock market; while Section 4 tracks the growth of the stock market in Kenya, in response to the reforms. Section 5 highlights the challenges facing stock-market development in Kenya. This is followed by the $6^{\text {th }}$ and concluding section.

\section{THE ORIGIN OF THE STOCK MARKET IN KENYA}

In Kenya, dealing in shares and stocks started in the 1920s, when the country was still a British colony. There was, however, neither formal market, nor rules or regulations to govern the stockbroking activities. Trading took place on the basis of gentlemen's agreements, in which standard commissions were charged, with clients being obligated to honour their contractual commitments of making good delivery and settling any relevant costs (Nairobi Stock Exchange, 1996). At that time, stockbroking was a side-line business conducted by accountants, auctioneers, estate agents and lawyers, who met to exchange prices over a cup of coffee. Because these firms were engaged in other areas of specialisation, the need for association did not arise (Nairobi Stock Exchange, 1996).

In 1951, an estate agent established the earliest professional stockbroking firm, and impressed upon the then-Finance Minister of Kenya the idea of creating a stock exchange in East Africa. Considering the proposal, which was given by the then-Finance Minister of Kenya and the estate agent, the London Stock Exchange officials approved, and agreed to recognise the creation of the Nairobi Stock Exchange, as an overseas stock exchange, in July 1953 (Nairobi Stock Exchange, 1996). In 1954, the Nairobi Stock Exchange (NSE) was established, with 46 listed companies, as a voluntary association of stockbrokers registered under the Societies Act (Chapter 108, Laws of Kenya). This was made possible after clearance was obtained from the London Stock Exchange, which recognised the NSE as an overseas stock exchange. This was important because an exchange not recognised by the 
leading stock exchange would be of little value. The business of dealing in shares was then confined to the resident European community, since Africans and Asians were not permitted to trade in securities until after the attainment of independence in 1963. This partly explains why it was difficult to convince the local people, who had hitherto been barred from holding Quoted Shares purely on racial grounds, that this institution was a vital vehicle for handing over economic power from foreign dominance to local control (Nairobi Stock Exchange, 1996).

In 1963, Kenya became independent, and Africans and Asians were permitted to deal in securities. In the first three years of independence, the economic development was stable, market confidence was restored, and the exchange operated several highly oversubscribed public issues (Nairobi Stock Exchange, 2002). At the dawn of independence, stock market activity slumped - due to uncertainty on the future of independent Kenya. However, after three years of calm and economic growth, confidence in the market was rekindled; and the NSE handled a number of highly over-subscribed public issues. The growth was, however, halted - when the oil crisis of 1972 introduced inflationary pressures on the economy, which depressed share prices (Nairobi Stock Exchange, 2002). A $35 \%$ capital gains tax was introduced in 1975, and later suspended in 1985; and this inflicted further losses to the exchange. At the same time, the NSE lost its regional character, following the nationalisations, exchange controls and other inter-territorial restrictions introduced in neighbouring Tanzania and Uganda. For instance, in 1976, Uganda compulsorily acquired a number of companies, which were either quoted, or were subsidiaries of companies quoted on the NSE (Nairobi Stock Exchange, 1996; Nairobi Stock Exchange, 2002).

The NSE is categorised into three market segments: i) Main Investment Market Segment (MIMS); ii) Alternative Investment Market Segment (AIMS); and iii) Fixed Income Market Segment (FIMS) (Capital Markets Authority, 2002). The MIMS is the main quotation market. Companies listed under this segment are further categorised into four sectors that describe the nature of their business, namely: a) agricultural; b) industrial and allied; c) finance and investment; and d) commercial and services (Capital Markets Authority, 2002). The AIMS provides an alternative method of raising capital to small, medium-sized and young companies that find it difficult to meet the more stringent listing requirements of the MIMS. The FIMS, on the other hand, provides an independent market for fixed income securities, such as treasury bonds, corporate bonds, preference shares and debenture stocks, as well as short-term financial instruments, such as treasury bills and commercial papers (Capital Markets Authority, 2002; Nairobi Securities Exchange, 2012).

The Exchange now operates an Automated Trading System, designed to electronically match buy and sell orders in a transparent process that involves member firms of the NSE placing bids and asking prices in a centrally accessible electronic order book. The benefits of this system include greater transparency in the placement of bids and offers. The system also improves market surveillance and transmits, almost in real time, trading information relating to index movements and the price and volume movements of traded securities. More current information will become readily available to a wider constituency of the market, facilitating the decision-making process, and reducing the risk of participating in Kenya's capital markets (Nairobi Securities Exchange, 2012).

The major functions of the NSE include the listing of companies, the settlement of trading, market administration and control, market surveillance, the publication of a monthly review, the monitoring of the activities of listed companies, and the announcement of price-sensitive, or other information, on listed companies through online channels.

\section{STOCK MARKET REFORMS IN KENYA}

In the 1980s, the Kenyan Government realised the need to design and implement policy reforms to foster sustainable economic development with an efficient and stable financial system. In particular, it set out to enhance the role of the private sector in the economy, to reduce the demands of public enterprises on the exchequer, to rationalise the operations of the public enterprise sector, to broaden the base of ownership, and to enhance the capital-market development, in general, and the stock-market development, in particular (Nairobi Stock Exchange, 2002).

In 1984, an International Financial Corporation (IFC)/Central Bank of Kenya study, the Development of Money and Capital Markets in Kenya, became a blueprint for structural reforms in the financial markets, 
culminating in the formation of a regulatory body (The Capital Markets Authority - CMA) in 1989, marking a shift from the self-regulatory system to the statutory regulatory system, to assist in the creation of an environment conducive to the growth and development of the country's capital markets (Nairobi Stock Exchange, 1996).

In 1991, the NSE was registered under the Companies Act; and it phased out the "Call-Over" trading system in favour of the floor-based "Open-Outcry System". Subsequently, the stock exchange embarked on an extensive modernisation exercise, including a move to more spacious premises at the National Centre in July 1994. These facilities include a modern Information Centre. Computerisation has also been enhanced, and with increasing trading volumes, electronic trading has now become feasible. In recent years, it acquired a central depository and settlement system, which has reduced settlement periods (Nairobi Stock Exchange, 1996).

In the same year, efforts were made to reduce listing costs, where the costs of initial public offerings for shares, debentures, and bonds were made tax-deductible expenses. In 1998, all the costs incurred by companies in the process of acquiring international credit rating were made tax deductible - in an effort to enable firms to access cheaper funds from foreign capital markets (Government of Kenya, 1996). However, part of these benefits were crowded by the costs charged by the CMA on market participants. Consequently, this, together with other listing requirements, failed to cut down significantly on the entry barrier for new companies (Nairobi Stock Exchange, 2002).

In 1995, the Kenyan Government also relaxed the exchange controls for locally controlled companies subject to an aggregate limit of $20 \%$, and an individual limit of $2.5 \%$. These were doubled to $40 \%$ and $5 \%$, respectively, in the June 1995 budget - to help encourage foreign portfolio investments (Government of Kenya, 1996). A series of incentives were put in place to encourage investments in the Nairobi Stock Exchange. These included a favourable tax regime that exempted listed securities from stamp duty, capital gains tax and value added tax. Withholding tax on dividends was low, at $5 \%$ for residents and $10 \%$ for non-residents (Government of Kenya, 1996).

The entire Exchange Control Act was repealed in December 1995 (Nairobi Stock Exchange, 1996; Nairobi Stock Exchange, 2002). The number of stockbrokers has grown steadily to 20 from the original six at its inception in 1954. Commission rates, which were once among the highest, have also come down considerably, from $2.5 \%$ to between $2 \%$ and $1 \%$, on a sliding scale for equities, and $0.05 \%$ for all fixed interest securities for every Shilling (Nairobi Stock Exchange, 1996; Nairobi Stock Exchange, 2002).

Further reforms in 2000/2001 introduced tax concessions of 50\% for newly listed companies for five years, provided the firm listed a minimum of $30 \%$ of its full issued and authorised share capital on the NSE, such that the newly listed companies paid a corporate tax of $25 \%$, as compared with $30 \%$ for the unlisted firms (Government of Kenya, 2001). New and expanded share capital by listed companies for those seeking listing was exempted from stamp duty. Expenses incurred by companies in having their financial instruments rated by an independent rating agency were made tax deductible.

Furthermore, in 2001 there were fundamental changes in the capital market, which reorganised the market into four segments to cater for different categories of firms (Capital Markets Authority, 2012b). In the same year, the Central Depository System (CDS) Act was passed by Parliament and sanctioned by the President in August 2000. The Capital Markets Authority Act was amended, and became known as the Capital Markets Act (Capital Markets Authority, 2012b).

In September 2006, an electronic trading system replaced the "open- outcry" method in an effort to boost trading volumes, and to speed up transaction times (Capital Markets Authority, 2012b). Despite the long history and efforts made to revitalise the stock market, the growth of the primary market is still very slow. For example, the number of listed firms presently is more or less the same as the number of firms listed before the beginning of the reform process.

It can also be noted that the stock exchange still suffers from concerns about liquidity, which cause investors to concentrate their funds on only about half of the listed stocks. Exchange officials expect, however, that 
an improved economic environment could boost the prospects of listed companies, making them more attractive targets for investors (Capital Markets Authority et al., 2011).

\section{STOCK MARKET GROWTH IN KENYA}

Before independence, the stock market experienced tremendous growth in the number of firms listed. The NSE had 46 listed companies by 1954, increasing to 50 in 1956. By 1959, the market had a total of 13 new listings and four delistings. In the 1960s, the number of new listings increased to 19, while the number of delistings rose to 11, such that the total number of listed companies increased from 56 in 1960, to 63 in 1969. During this period, locally controlled companies made a significant entry. The Government, which was enthusiastic about the gains of political independence, made deliberate efforts to encourage the financial system (predominantly the banking sector) to provide credit facilities to those wishing to purchase shares - both in the primary and secondary markets. As a result, most of the initial public offers (IPOs) were heavily over-subscribed (Ministry of Economic Planning and Development, Kenya, 1967).

Data indicate that in the period 1966-1970, the industrial sector dominated - with $42 \%$ of the total number of issues made, and 74\% of the total value raised (Capital Markets Authority, 2012b). The period following the establishment of Capital Issues Committee saw a high number of delistings (11) compared with new listings (7), such that the total number of firms listed declined from 64 in 1970, to 57 in 1979. Two of the delisted firms followed the break-up of the East African Community. Two companies were taken over; two voluntarily wound up; and one reduced its capital (Capital Markets Authority, 2012b).

During the period 1980-1989, only three initial public offers were made. These were mainly made by financial institutions; and one of them was a divestiture of government shares. Growth in the number of listed companies, however, was very marginal - mainly because of the minimal number of new initial public offers issued and the delisting of various companies. The total number of listed firms was, therefore, 57 in 1989, similar to the level in 1980. Due to the delistings, the reform period had a generation of new companies to replace the companies originally listed when the market had opened its doors, and an increased proportion of locally controlled companies (Nairobi Stock Exchange, 1997).

In the reform period 1990-1999, nine (9) new public offers were made, of which four (4) were part of the ongoing privatisation process of government parastatals (Nairobi Stock Exchange, 1997). By 1998, the market had 58 companies and 69 securities listed on the stock exchange. Of the total listed companies, $72 \%$ were locally controlled; while the industrial and allied sector took the highest percentage (30\%) of the total listed companies. Only $35 \%$ of the total listed firms were included in the calculation of the NSE Index 1 (Nairobi Stock Exchange, 2002). The minimal number of new listings indicates that the implemented reforms did not achieve much in attracting the listing of private companies.

The period from the year 2000 witnessed the listing of the first information technology firm and the first sugar firm. The two issues fetched about Ksh 1500 million; but unlike the previous offers, they were undersubscribed, signalling a growing listing risk (Nairobi Stock Exchange, 2002). Under subscription was attributed to the depressed market and declining individual disposable income following the economic downturn, coupled with an investment mood that seemed to favour secure high-yielding government securities (Nairobi Stock Exchange, 2002). In addition, three companies were delisted from the year 2000 (Nairobi Stock Exchange, 2002).

By September 2005, the market had 50 active listed companies, of which $20 \%$ were listed on the Alternative Investment Market Segment Board (Nairobi Securities Exchange, 2012). The industrial and allied sector had the highest share of listed firms (36\%); while the agricultural sector had the least (14\%) (Nairobi Securities Exchange, 2012). Currently, there are about 60 listed companies (Nairobi Securities Exchange, 2012). Chronologically, there were 56 listed companied in 1960, 63 in 1969, and 64 in 1970. From a peak of 64, the number of listed companies dropped to 57 in 1979, it remained stagnant at 57 in 1989, it increased slightly to 58 in 1998, before decreasing to 50 in 2005, and increasing again to 60 in 2012 (Nairobi Securities Exchange, 2012).

The growth of the stock market in Kenya can also be explained by using the stock market capitalisation of listed companies, the total value of stocks traded, and the turnover ratio of stocks traded. The market capitalisation 
ratio is usually equal to the value of the listed shares divided by the GDP; and analysts frequently use this ratio as a measure of the stock market size. The stock market size of Kenya was stagnant in the late 1980s, and it only started improving in 1991, reaching 43\% in 1994, before it deteriorated, creating a deep and wide trough between 1995 and 2006. The market size improved vastly between 2001 and 2006. Although the late 2000s registered stock market capitalisation of $50 \%(0.5)$, this is still very low when compared to most of the high income countries' registered stock market capitalisation ratio of 155\% (1.55) (World Bank, 2012). Figure 1 tracks the performance and growth of the stock market in Kenya, using the stock market capitalisation of listed companies during the period 1988-2010.

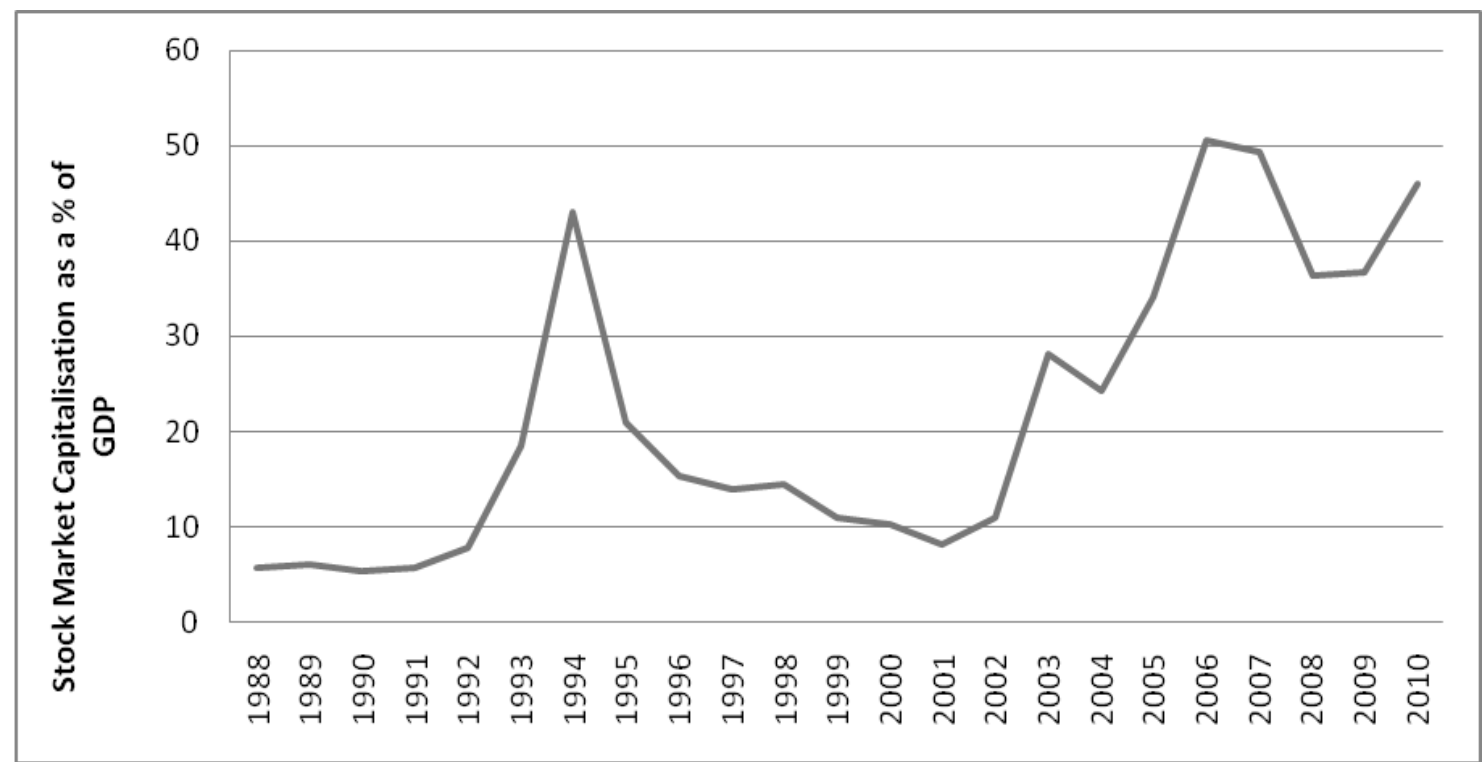

Figure 1: Stock Market Capitalisation (1988-2010)

Source: World Bank Development Indicators (2012)

Liquidity is also used to assess the stock market development in Kenya. While economists advance many theoretical definitions of "liquidity", analysts generally use the term "liquidity" to refer to the ability to easily buy and sell shares and stocks. Although a comprehensive measure of liquidity would quantify all the costs associated with trading, including the time costs and the uncertainty of finding a counterpart and settling the trade, this study simply uses two measures of realised stock trading.

The total value traded was low and constant, at below 2\% (0.02) for a decade, between the early 1990s and the early 2000s. Thereafter, it picked up over the years to $6 \%$ in 2006, before it fell to $2 \%$ again in 2009. It is interesting to note that Kenya's stock market capitalisation and total value traded showed a similar trend, where market capitalisation improved, the total value traded improved, and vice versa. However, market capitalisation was more elastic than total value traded. In general, market capitalisation was somewhat higher; while total value traded was lower from 1990 to 2003, meaning there was little trading. The markets were, in general, less liquid. From 2004 onwards, the total value traded improved, reflecting a liquidity improvement; and hence, the development of the stock market (World Bank, 2012). Figure 2 tracks the performance and growth of the stock market in Kenya, using the total value of stocks traded during the period 1988-2010. 


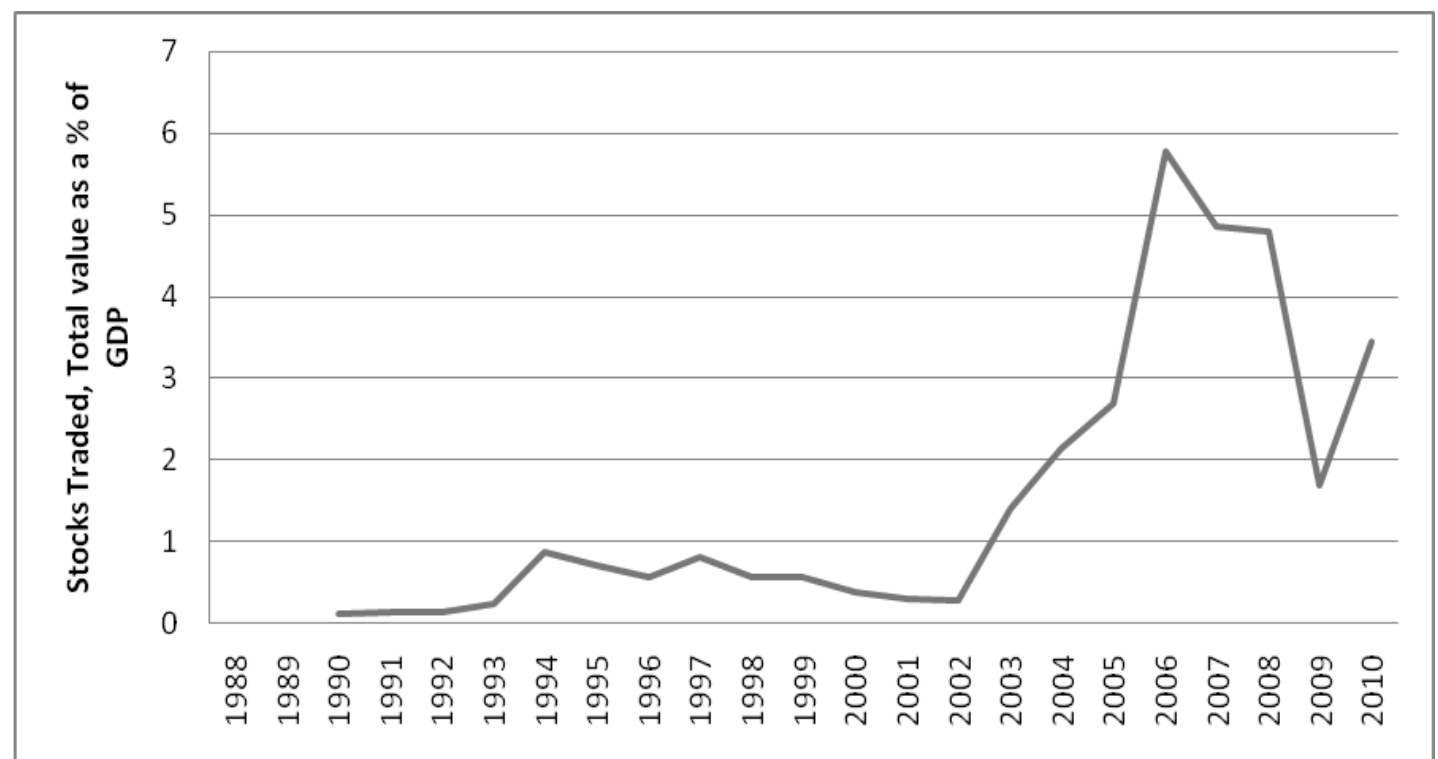

Figure 2: Total Value of Stocks Traded (1988-2010)

Source: World Bank Development Indicators (2012)

As with the total value traded, the turnover ratio was also low, averaging 4\% (0.04) from 1990 to 2002, reflecting a less active stock market. There was, however, an improvement in the activity of the market between 2002 and 2008, as depicted by the rising turnover ratio. It may be noted that the three measures of stock market development used in this study reflect the same trend, although with differing elasticity. This can be explained by the market-based policies put in place, which affected these three proxies of market-based financial development in the same way. Figure 3 tracks the performance and growth of the stock market in Kenya using the turnover ratio of stocks traded during the period 1988-2010.

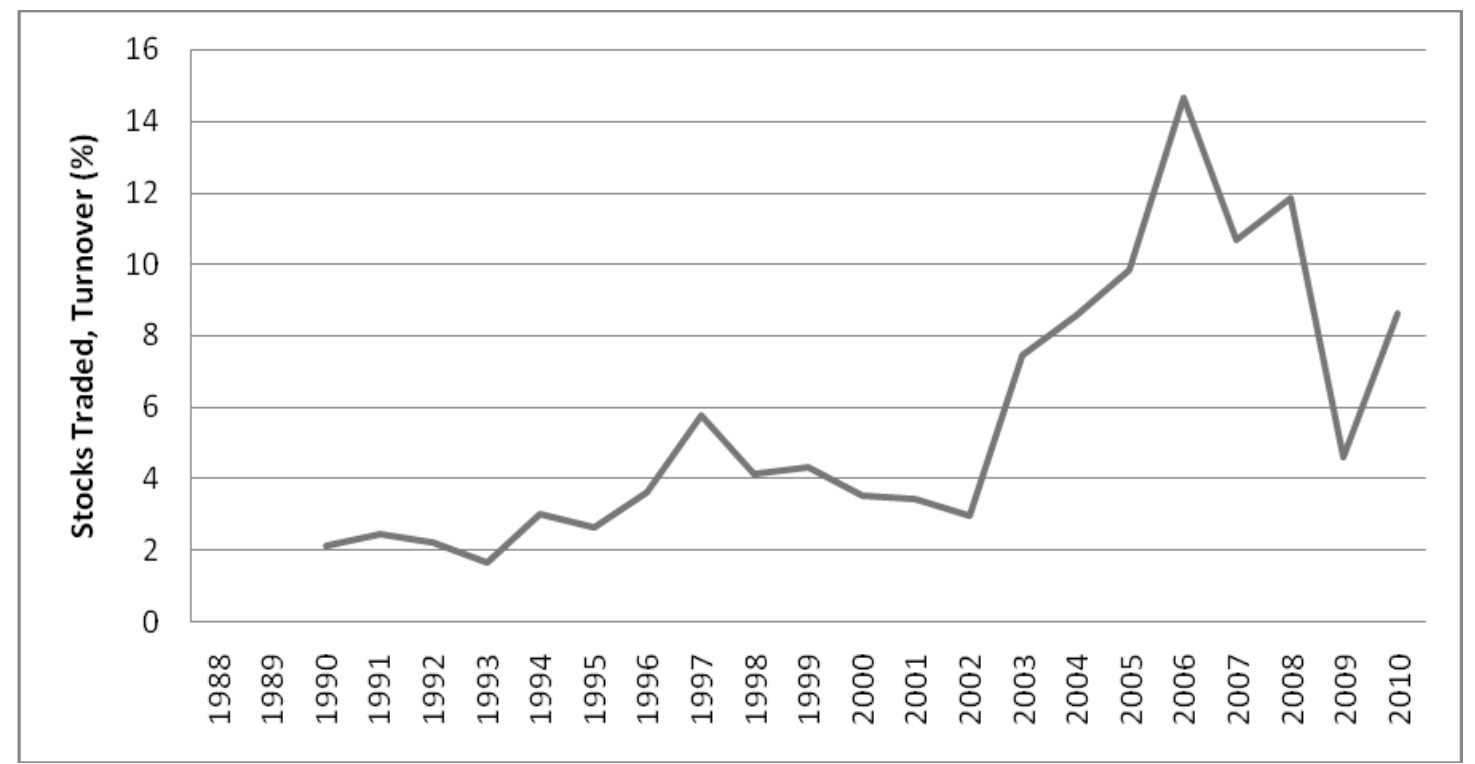

Figure 3: Turnover Ratio of Stocks Traded (1988-2010)

Source: World Bank Development Indicators (2012) 


\section{CHALLENGES FACING THE STOCK MARKET DEVELOPMENT IN KENYA}

Kenya's stock market is faced with a wide range of challenges. These include: a lack of awareness, low investor confidence, a lack of competitive pressure in the local market, vulnerability to shocks, and the low level of the capital market liquidity. Generally, there is lack of awareness and information on the role, functions and operations of the stock exchange and the CMA among potential investors and business entities. Many Kenyans throughout the country do not know enough about the NSE and the CMA; and the market does not seem to market itself adequately to potential investors, or to provide a variety of products to attract companies. This may be attributed to financial and human resource constraints (Capital Markets Authority et al., 2011). The lack of public awareness on NSE operations is a major hindrance to corporate participation in the stock market (Capital Markets Authority et al., 2011).

The low level of capital market liquidity is a major challenge facing Kenya's stock market (Capital Markets Authority, 2012b). Although the NSE is generally considered a more liquid and active market than most of its East African counterparts in sub-Saharan Africa, by international standards it is small, less liquid and volatile with regard to price and returns. Low liquidity is particularly evident in the secondary bonds and in the equity markets (Capital Markets Authority, 2012b). In addition, there is a high incidence of "buy and hold" particularly among institutional investors, who dominate the market. (Capital Markets Authority, 2012b).

Increasing listing at the NSE has always been a challenge, especially in recent years. Over the last fifteen years, the number of stocks traded at the NSE has stagnated at around 55 quoted companies (Nairobi Securities Exchange, 2012). Currently, there are sixty (60) listed companies in contrast to the hundreds of companies involved in Kenya (Nairobi Securities Exchange, 2012). Limited listings have a negative impact on the supply of new equities. The limited supply of new equities in the capital market has restricted the use of the equity market as a source of financing. In view of the past failure to attract new equity, the most difficult hurdle for the NSE is increasing the number of medium-sized and large family-owned businesses and state-owned companies operating in Kenya and listed on the NSE (Nairobi Securities Exchange, 2012).

Generally, the main factors limiting the supply of shares include the reluctance of small, family-owned businesses to dilute ownership, the costly and tedious process of making public offers, and the perception by many eligible companies that the risks associated with additional disclosure are not adequately compensated for by additional returns (Capital Markets Authority, 2012b). High real short-term interest rates have reduced the demand for capital market instruments and crowded out substantial domestic savings to short-term government securities (Capital Markets Authority, 2012b). This situation was particularly evident in 2001, when the treasury bill rate was $12.6 \%$ compared to an inflation rate of $0.8 \%$. However, the situation is being reversed, as treasury-bill rates have fallen to about $8 \%$ - resulting in an increased demand for both equity and debt instruments (Capital Markets Authority, 2012b). According to Nairobi Securities Exchange (2012), interest rate spreads are high; and currently, they are standing at about $13 \%$. Deposit rates are too low and lending rates too high, thereby discouraging domestic savings and investment. The domestic savings are less than 10\% of GDP; and they are consequently insufficient to meet investment needs, and to generate any significant demand for equities and debt instruments (Nairobi Securities Exchange, 2012).

The stock market in Kenya is vulnerable to market shocks, as the method of determining share prices may result in the market capitalisation of a counter being heavily affected by a small lot deal. People and businesses have low confidence in the performance of capital markets. They also have a perception of low standards of corporate governance, since neither the NSE nor the brokers publish their corporate governance report (Capital Markets Authority et al., 2011). As a result, players in such a market are limited; and any efforts to innovate the market are not well-cultivated, thereby leading to another challenge, which is the slow pace of innovation and the flexibility and limited access to capital. Deep markets are constantly developing products, such as securities, derivatives and options - for both funding and risk management. The capital markets in Kenya have been slow in developing products; and they have left companies to depend on the short-term money markets (Nairobi Stock Exchange, 2002). 


\section{CONCLUSION}

This paper has discussed the origin of the stock market in Kenya, the reforms undertaken to develop the market, the growth of the stock market, as well as the challenges facing stock market development in Kenya. Kenya has one stock exchange, where the trading of stocks takes place. This is known as the Nairobi Securities Exchange, formerly known as the Nairobi Stock Exchange. Although Kenya's stock market is one of the largest stock markets in Africa, it is still young and developing by the standards of advanced economies. In order to foster stock market development in the country, a number of reforms targeting the stock market have been implemented over the years. These include the formation of a regulatory body (the CMA), marking a shift from the self-regulatory system to the statutory regulatory system; the replacement of the "Call-Over" trading system, in favour of the floor-based "OpenOutcry System", the reduction of listing costs, the relaxation of the exchange control for locally controlled companies, and the repeal of the Exchange Control Act. Following these reforms, Kenya's stock market has developed significantly in terms of market capitalisation, the total value of stocks traded, and the turnover ratio. Although the stock market in Kenya has developed over the years, as evidenced by the increasing stock market capitalisation, the total value and turnover ratio of stocks traded at the beginning of 2001, the market did not grow in terms of the number of listed companies. Currently, it has about 60 listed firms, which are less than the number of listed firms during the pre-reform period. The challenges faced by the stock market development in Kenya include a lack of awareness, low investor confidence, a lack of competitive pressure in the local market, a vulnerability to shocks, and the low level of liquidity in the capital market.

\section{AUTHOR INFORMATION}

Sheilla Nyasha, Doctoral Candidate, Department of Economics, University of South Africa (UNISA), South Africa. E-mail: smagombeyi@yahoo.com (Corresponding author)

Prof Nicholas M. Odhiambo, Professor \& Research Chair: Macroeconomic Policy Analysis (MPA) Research Programme, University of South Africa (UNISA), South Africa. E-mail: odhianm@unisa.ac.za and nmbaya99@yahoo.com

\section{REFERENCES}

1. Allen, F., \& Faulhaber, G. R. (1989). Signalling by under-pricing in the IPO market. Journal of Financial Economics, 23, 303-323.

2. Beck, T., et al. (2010). Banking sector stability, efficiency, and outreach in Kenya. The World Bank Policy Research Working Paper 5442.

3. Capital Markets Authority. (2002). Capital markets authority 2002 annual report.

4. Capital Markets Authority. (2012a). How does the stock market work. Accessed June 8, 2012. http://www.cma.or.ke/index.php?option=com_content\&task=view\&id=10\&Itemid=24

5. $\quad$ Capital Markets Authority. (2012b). Various issues. Accessed June 8, 2012. http://www.cma.or.ke/index.php?option=com_content\&task=view\&id=16\&Itemid=36

6. Capital Markets Authority, Central Bank of Kenya, Insurance Regulatory Authority, Retirement Benefits Authority, Sacco Societies Regulatory Authority, Ministry of Finance and Ministry of Co-operative Development and Marketing. (2011). Kenya financial sector stability report 2010. The Joint Regulators Board.

7. Demirguc-Kunt, A., \& Levine, R. (1996). Stock market development and financial intermediaries: Stylised Facts. World Bank Economic Review, 10(2), 341-369.

8. Garcia, V. F., \& Liu, L. (1999). Macroeconomic determinants of stock market development. Journal of Applied Economics, 2(1), 29-59.

9. Government of Kenya. (1996). Economic reforms for 1996-1998: The policy framework paper. Prepared by the Government of Kenya in collaboration with the IMF and the World Bank.

10. Government of Kenya. (2001). Poverty reduction strategy paper for the period 2001-2004. Government Printer, Nairobi.

11. International Monetary Fund, and Central Bank of Kenya. (1984). Development of money and capital markets in Kenya. Government Printer. Nairobi. 
12. Ministry of Economic Planning and Development. (1967). Economic survey. Government Printer, Nairobi.

13. Nairobi Securities Exchange. (2012). Various issues. Accessed May 4, 2012. http://www.nse.co.ke/

14. Nairobi Stock Exchange. (1996). Retrieved May 4, 2012 from http://www.nse.co.ke/about-nse/history-oforganisation.html

15. Nairobi Stock Exchange. (1997). Annual report. Nairobi Stock Exchange. Nairobi.

16. Nairobi Stock Exchange. (2002). Handbook: An authoritative 5-year performance results of listed companies. Nairobi Stock Exchange. Nairobi.

17. World Bank. (2012). World Bank Development Indicators. Accessed January 15, 2012. http://data.worldbank.org/topic/financial-sector

18. Yartey, C. A., \& Adjasi, C. K. (2007). Stock market development in sub-Saharan Africa: Critical issues and challenges. IMF Working Paper 07/209. International Monetary Fund, Washington DC. 